\title{
A multidisciplinary approach to the spatial dimension in ecosystem-based fisheries management
}

\author{
Pascal Le Floc' $h^{1,{ }^{*}}$, Michel Bertignac ${ }^{2}$, Olivier Curtil ${ }^{1}$, Claire Macher ${ }^{3}$, Emilie Mariat-Roy ${ }^{4}$ and \\ Yves-Marie Paulet ${ }^{5}$ \\ ${ }^{1}$ University of Brest, IUEM-AMURE, rue Dumont d'Urville, 29280 Plouzané, France \\ 2 IFREMER, Laboratoire de biologie halieutique, ZI de la Pointe du Diable, 29280 Plouzané, France \\ ${ }^{3}$ IFREMER, AMURE, rue Dumont d'Urville, 29280 Plouzané, France \\ 4 CETMA, MNHN, ApoliMer, rue Dumont d'Urville, 29280 Plouzané, France \\ ${ }^{5}$ University of Brest, IUEM-LEMAR, rue Dumont d'Urville, 29280 Plouzané, France
}

Received 4 December 2017 / Accepted 13 July 2018

Handling Editor: Verena Trenkel

\begin{abstract}
This study considers how to reconcile different spatial scales to find the best common denominator to be used as an ecosystem-based management unit. For this, two fishery production zones differing ecologically, economically, legally and institutionally were investigated. The first case study is located within French territorial waters, in a MPA created in 2007- the Parc Naturel Marin d'Iroise (PNMI). The second case study, the Bay of Biscay, covers both territorial waters and the French exclusive economic zone. The paper adopts a multidisciplinary approach. Relevant questions concern how marine space is shared between exploited species and fishing fleets, especially the spatial mobility strategies they employ. An assessment of the institutional system established for the PNMI contributes to the discussion of changes in coastal space use. It is obvious that the area in need of protection, defined on the basis of essential fish habitats, does not solely concern the fisheries located within the coastal zone. Experiments conducted by scientists and professionals in the Bay of Biscay provide other key points for the discussion in terms of what institutional frameworks to promote.
\end{abstract}

Keywords: Spatial scale / ecosystem-based fisheries management / marine protected area / socio-system

\section{Introduction}

In the fisheries literature, ecosystem-based fisheries management (EBFM) is presented as an intermediate level between single stock fisheries management (SSFM) and ecosystem based management (EBM) (Link and Browman, 2014). While the final objective is a holistic approach using EBM, the difficulties on the way from SSFM to EBFM are not easy to resolve (Cormier et al., 2017). Historically European fisheries have been managed by SSFM, based on the identification of a set of key stocks from a commercial perspective. In Europe, the single species stock-specific approach is profoundly rooted in the institutions of EU member states, with a legislative umbrella specific to the fishing industry (Van Hoof, 2015). This is the case also elsewhere. In Canada, the 1867 Constitution includes a section that places the fisheries sector under the responsibility of the

\footnotetext{
*Corresponding author: plefloch@univ-brest.fr
}

federal government (Parsons, 1995). In the US, the law on fisheries is more recent with the adoption of the MagnusonStevens Act in 1976 (Biedron and Knuth, 2016). Lastly, in 1970, the member states of the European Union developed a Common Fisheries Policy (CFP) that was adopted in 1983 (Churchill and Owen, 2010). The progressive adoption of the ecosystem approach has led to specific legislation for fisheries in Canada, the US and the EU at a lower level, embedded in a higher-level organizational structure. The central authority is now in charge of planning an EBFM or EBM: the Oceans Act in Canada (2005), the National Ocean Policy in the US (2010) and the Marine Strategic Framework Directive (MSFD) in the EU (2008). In the EU, adopting a multi-species management plan for implementing EBFM or EBM is the only possible way for coastal states. Less clear is the scope of future fisheries management, under EBFM or the more ambitious EBM including cumulative impacts of several activities in the same geographic area (Fig. 1). For EBFM, sectors other than fisheries (as such tourism, sea-based events, marine energy platforms, climate change) impacting fish habitats and fish 


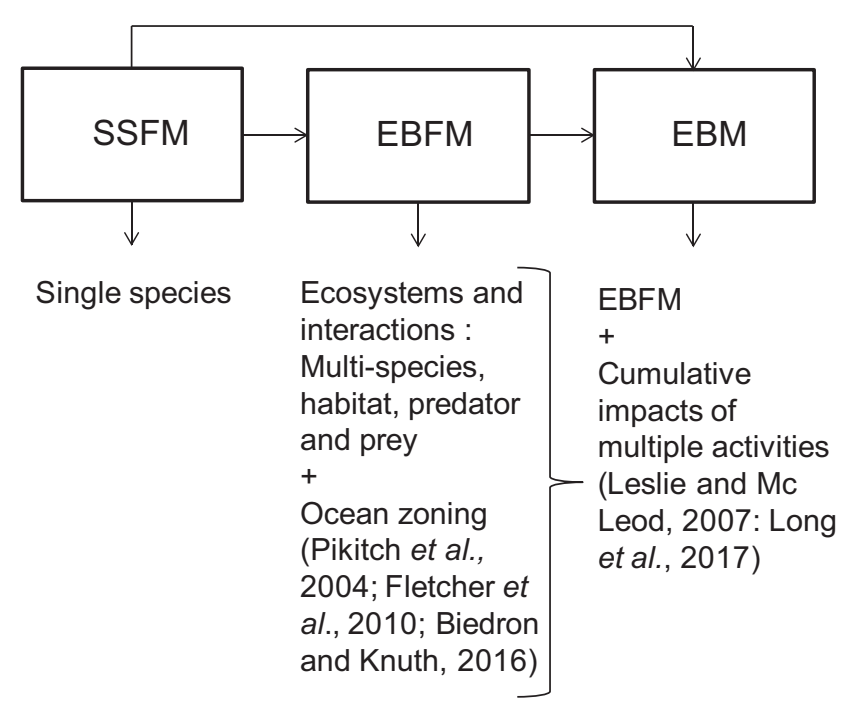

Fig. 1. From SSFM to EBFM and EBM.

stocks are defined as external drivers while they are considered internal drivers for EBM. The delineation of spatial areas (marine protected areas, Territorial Use Rights for Fishing or TURFs, reserves, habitat restoration areas, ocean zoning...) is an operational tool to move from SSFM towards EBFM and EBM (Fletcher et al., 2010).

This study focused on the operational phase of EBFM, in particular the appropriate spatial units for a multidisciplinary perspective. Indeed, ecosystem-based management relies on ecological and socio-economic management objectives on different spatial scales, mainly a regional level for coastal zone management and regional ocean planning (Smith et al., 2007). Protection of the marine ecosystem requires the alignment of the geographic areas in which species and fishing fleets are distributed. The institutional dimension also adds another perspective on space, depending on the governance system in place. In this multidisciplinary context, defining spatial units generates more complexities for resource management strategy, which makes it difficult to reconcile ecological, economic, legal and institutional approaches. The challenge consists in reconciling different spatial scales and finding the best common denominator to be used as an ecosystem-based management unit.

The present research is based on two fishery production zones that differ ecologically, economically, legally and institutionally. The first case study, Parc Naturel Marin d'Iroise (Iroise Natural Marine Park), is located within France's territorial waters, thus represents a purely coastal spatial scale. It is France's first marine park, which benefits from both the contribution of maritime activities to sustainable development and research aimed at better understanding the marine environment (Daurès et al., 2011). The institutional system grants to Member States by the European Union an exemption which allows them to take management measures decentralised. In this context the management board of the marine park has an advisory role. The characteristics of this case study, i.e. only coastal fisheries, fishers based in one member state only and located in or near the park, and the institutional system in charge of protecting the environment, should ensure that spatial units can be easily aligned for ecosystem-based management in a multidisciplinary context.

The second case study is the Bay of Biscay. It covers both territorial waters and the exclusive economic zone (EEZ) which is the area extending over 200 nautical miles from the baselines. The Bay of Biscay is home to a large number of commercial species, mostly exploited by French and Spanish fleets (Daurès et al., 2009). The institutional system for the territorial sea part is identical to that of the first case study, i.e., an exemption system based on a shared decision-making process established between the regional prefect, representing the French government, and the regional fishing committee. Beyond the coastal zone, fishing is managed under the exclusive jurisdiction of the European Union, without any exemptions for member states. The standard tools of the CFP are applied, such as TACs (total allowable catches) for management units based on ICES spatial zones. Reconciling the biological, economic, legal, and institutional spatial units is expected to be more difficult than for the first case study due to the interaction between species (coastal-to-ocean zones) and between fleets using various fishing methods, and due to vessels being registered in different ports, mainly French and Spanish ports on the Atlantic coast.

The first section of this paper describes the spatial dimension of the socio-systems using a multidisciplinary approach, fostered by pioneering studies on the interactions between nature and man from an economic and ecological viewpoint. For this we mainly draw on the converging works of E. Ostrom, S. Levin and D. North. The second section proposes an interpretation of socio-systems applied to fisheries. It identifies key concepts from life sciences (marine biology and ecology) and social sciences (economics, law, anthropology and sociology) that together offer multidisciplinary insights regarding the appropriate spatial area for successful implementation of EBFM. The spatial issue is important in the transition from SSFM to EBFM. Some authors refer to ocean zoning (Pikitch et al., 2004) or geographic scales "to understand how social and ecological processes interact" (Leslie and McLeod, 2007). Another approach, not directly related to the physical description of space, identifies an EBFM frontier as a result of fishing strategies applying species portfolio theory (Sanchirico et al., 2008). The third section examines then two case studies. Drawing on the previous sections the final section discusses the spatial scales most suitable for EBFM.

\section{The spatial dimension in socio-systems}

Integrating social and ecological dimensions can lead to a better understanding of complex systems (Holling, 2001). Research on the modelling of socio-systems or socioecological systems requires interdisciplinary research involving life scientists and social scientists (Mazé et al., 2017; Villasante et al., 2013; Berkes, 2006).

E. Ostrom's work on socio-systems laid the foundations for this type of empirical research. It highlighted the interdependence of production systems with different spatial scales, which affects the behaviour of the actors involved: "Linking the broader contextual variables and microcontextual variables is one of the major tasks facing scientists who work across 
Table 1Key concepts of socio-systems; arrows indicate similarities.

\begin{tabular}{lll}
\hline Polycentric systems (Ostrom, 1990) & $\begin{array}{l}\text { Complex adaptive systems (Levin, 1998; } \\
\text { Holling, 2001) }\end{array}$ & Institutions (North, 1990; Arthur, 1989) \\
\hline Legal instruments Property rights & Path dependency & Formal and informal rules Role of history \\
\hline Boundaries Systemic integration & Integration of energy fluxes & \\
\hline & Diversity and key species & \\
\hline
\end{tabular}

disciplinary lines to understand how both social and ecological factors affect human behaviour." (Ostrom, 2010). Hence, human and social sciences have contributed to the studies conducted by ecologists on ecosystems. We therefore first review three methodological notions and concepts that offer an interpretation of the spatial dimension of sociosystems: polycentric systems, complex adaptive systems and the role of institutions.

Polycentric management systems have several properties (Ostrom, 2008; Platteau, 2004; Trawick, 2001; Berkes et al., 1989). We chose four properties for the present study: (i) clearly defined boundaries for the shared resource pool, (ii) legal instruments for resolving conflicts, accompanied by monitoring and sanction measures, (iii) recognition of property rights, (iv) integration of exploitation systems into a broader institutional framework (Ostrom, 1990, 2008).

In a description where population dynamics play an important role, S. Levin used the concept of complex adaptive systems drawing on the evolutionary science literature (Levin, 1998; Levin, 2000). The spatio-temporal dynamics of an ecological system depend on how it functions endogenously, with no overall controller. Among the properties of complex adaptive systems are (i) aggregation of individuals into populations, which in turn are grouped into functional groups; (ii) non-linear changes, explained by path dependency (Arthur, 1994); (iii) necessity for key species to be present; and (iv) energy and information flow that connect local ecosystems to make it part of a larger whole. The last property coincides with the notion of integration of exploitation systems found in Ostrom's work (Ostrom, 1990; 2008). Levin addressed the spatial dimension through species migration phenomena and their dynamics in nested or overlapping ecosystems.

Addressing the role of institutions brings us to the work of D. North (1990). The institutional scale is first identified according to the type of rules applied for exploiting common natural resources. North distinguishes between formal rules drawn up within a legal framework and informal rules based on customary laws, traditions passed down through generations, or codes of conduct within a community (North, 1991). The second core element for analyzing institutions is the role played by history as a source of path dependency, a notion we also find in the theory of complex adaptive systems. This notion, developed from research in economics of technical change during the 1980s (Nelson and Winter, 1982), was echoed in the analysis of institutions (Pierson, 2000). The properties recognized as inherent to the path dependency phenomenon are self-reinforcement mechanisms: collective memory, learning and a form of adaptive expectation of events. We can approach this capacity for institutions to self-reinforce within the dynamics of an ecological system from the point of view of endogenous behaviour, as described by Levin in complex adaptive systems (Levin, 1998). The role of history determines the choices and conducts of individuals, sometimes provoking a lock-in phenomenon around a decision as a result of these self-reinforcement mechanisms (Arthur, 1989). Reproducing previous behaviour poses a threat to institutional reforms. Crisis situations can also give rise to a renewal of institutions, revealing the capacity of fishers to adapt their routines through innovation (Grafton, 2005; Gutierrez et al., 2011; Coulthard, 2012). The spatial question is also present in the analysis of institutions. It actually becomes essential when discussing the possible organizational forms a natural resource management system can take, from centralised, and therefore remote from producers, to co-managed, where actors are at the heart of the decision-making process (Jentoft, 1989; Sen and Nielsen, 1996).

Theoretical contributions on socio-systems partly break down the barriers between different disciplinary approaches. The question of spatial scale is dealt with on two levels in the description of polycentric systems. If boundaries between resource pools exploited by different communities are not clear, conflicts are more likely to occur. In fisheries, user conflicts often occur within the same resource pool, either through competition between fishing gears (active versus passive gears), or because of ill-defined access and production rights. The imbalance between the availability of a resource and the level of fishing effort required, along with restricted access, sometimes leads to conflicts between communities (Charles, 1992). The second spatial level raises the question of the integration of resource pools. This aspect is especially pertinent for fishing activities where coastal fisheries operating in a territorial sea overlap with fisheries operating beyond the 12-nautical-mile boundary (Guyader et al., 2013).

In complex adaptive systems, Levin put greater emphasis on temporal dynamics, which complements the spatial dynamics of species (Levin, 2000). He recognised the importance of the path dependency concept, which sometimes creates a lock-in around a situation that makes its reversal difficult. The recognition of path dependency by ecologists echoes North's works on institutions. The most famous irreversible case to date in fisheries is the moratorium on industrial fishing in the Northwest Atlantic in 1992, justified by the collapse of cod stocks (Parsons, 1995; Palmer and Sinclair, 1997; Schrank, 2005).

Table 1 shows the key concepts provided by studies on socio-systems and identifies similarities. The identification of geographic boundaries is a first step towards structuring marine spaces. The crossing points between defined spaces, overlapping or juxtaposed, produce interactions called integration by Ostrom and Levin. To make this step the 
following questions need to be answered. Which definition of marine space should be used? How to evaluate the interactions between the different identified spaces?

A second set of questions arises relative to legal instruments, property rights, and path dependency (or North's role of history). Some rules for managing a resource pool are based on customary law, acknowledged by the community, or more generally, on formal rules when institutions have legal legitimacy. During crisis periods, the legitimacy of institutions representing fishermen is sometimes brought into question by a more radical base - a phenomenon observed several times in the French fishing industry (Le Floc'h and Wilson, 2017).

Path dependency, described by Levin and North, poses the challenge of how populations within an ecosystem cope with a structural change that modifies spatial and temporal dynamics. The notion of resilience often appears in multidisciplinary approaches to socio-systems (Levin et al., 1998; Berkes and Folke, 1998; Walker et al., 2004; Mariat-Roy, 2014; Bousquet et al., 2016).

A third type of reflection, defining what a socio-system actually is in relation to resource exploitation, tackles the question of key species and ecosystem diversity. This crucial issue is clearly present in the works of Levin, but it is not restricted to research on marine biology and ecology. The concept of key species is also essential for fishery economists for measuring performance indicators. Both case studies selected in this paper are strongly dependent on key commercial species from two fishing areas: the Bay of Biscay (ICES subdivisions VIIIa and VIIIb) and the Celtic Sea (ICES subdivisions VIIh and VIIj). These are important fishing areas for the French fishing fleet targeting cod (Gadus morhua), hake (Merluccius merluccius), anglerfish (Lophius piscatorius and Lophius budegassa), nephrops (Nephrops norvegicus), pollock (Pollachius pollachius), seabass (Dicentrarchus labrax) and sole (Solea solea). This list of key species does not cover all landed species (targeted and by-caught). Other definitions of key species are pertinent in ecology and social sciences. Selecting key species is an entry point for the definition of the most appropriate geographic area, through the spatial mobility strategies of fishing companies. As such, it is also of interest to anthropology dealing with certain emblematic species (Acheson, 1975; Durrenberger and Palsson, 1987).

\section{Socio-systems and fisheries}

\subsection{Boundaries: spatial scales}

The European Union exercises sole jurisdiction over all waters under the jurisdiction and sovereignty of member states, including territorial seas. By exercising the sole jurisdiction for "the conservation of marine biological resources under the CFP", the European Union is not bound by spatial divisions and member state borders. However, in the exercise of this right, the European Union has decided to delegate power to member states to take measures for the conservation and management of fish stocks within an area consisting of the 12 nautical miles of so called territorial sea. In compliance with CFP objectives, a member state can take all necessary measures to protect marine resources and ecosystems within the 12-nautical-mile boundary, "provided that the Union has not adopted measures addressing conservation and management specifically for that area or specifically addressing the problem identified by the member state concerned (Article 20 of Regulation 1380/2013)". The delegation of power in territorial seas is coupled with a privileged access granted to vessels from the member state, as a result of an exemption from the principle of equal access to resources in all Union waters for fishing vessels flying the flag of other member states. Member states are authorised to restrict fishing to vessels "that traditionally fish in those waters from ports on the adjacent coast". Indeed, this set-up suggests that access to these waters is reserved for nationals of the member state (European Parliament and Council, 2013).

\subsection{Institutions and resilience}

In France, the government has delegated the management of fisheries to the regional prefect and regional fishing committee. This institutional mechanism partly adheres to the principle of regionalisation by transferring decision-making power to stakeholders located close to the resource pool (Eliasen et al., 2015; Van Hoof, 2015). From a fisheries perspective, stocks sustained by coastal waters (or strictly local stocks) are sometimes omitted from the Community or European quota system. Hence, species not managed under a TAC at the European level are concerned by this delegation of powers to member states in compliance with Article 10 of Regulation 3760/1992 of the CFP.

The complexity of the institutional framework covering territorial seas can reinforce the path dependency phenomenon, a concept applied to human populations in North's work and to communities of exploited species in Levin's work. It is interpreted as resistance of a community or population to change, which is also described by Levin as the resilience of the system as a whole: "Such resistance to change can be interpreted as resilience [...]. Path dependency is a consequence of nonlinearity, which refers simply to the fact that the local rules of interaction change as the system evolves and develops (Levin, 1998)". In fisheries, examples of path dependency are nonlinear, demonstrating the capacity of fishermen to correct errors from the past through adaptive expectations (North, 1991). These corrections sometimes lead to innovative behaviour, either in terms of organisation or through learning about new tools, as it happened for the seaweed harvesting fleet of Northwest Brittany and fisheries management under the control of the local community (Alban et al., 2004).

\subsection{Key species and mobility}

The concept of key species raises potential conflicts between institutional managers and scientists, as fishery management is based on fish markets, whereas nature conservation is not bound by commercial considerations for defining key species. The European Union adopts a commercial criteria when setting total allowable catches (TAC) for key species. Estimations of physical capacity use for instance a species-by-species basis for a selection of key species which are commercially exploited (Pascoe et al., 2001). For ecology and nature conservation, the notion of key species does not relate to commercial interest and markets. In ecology, key 


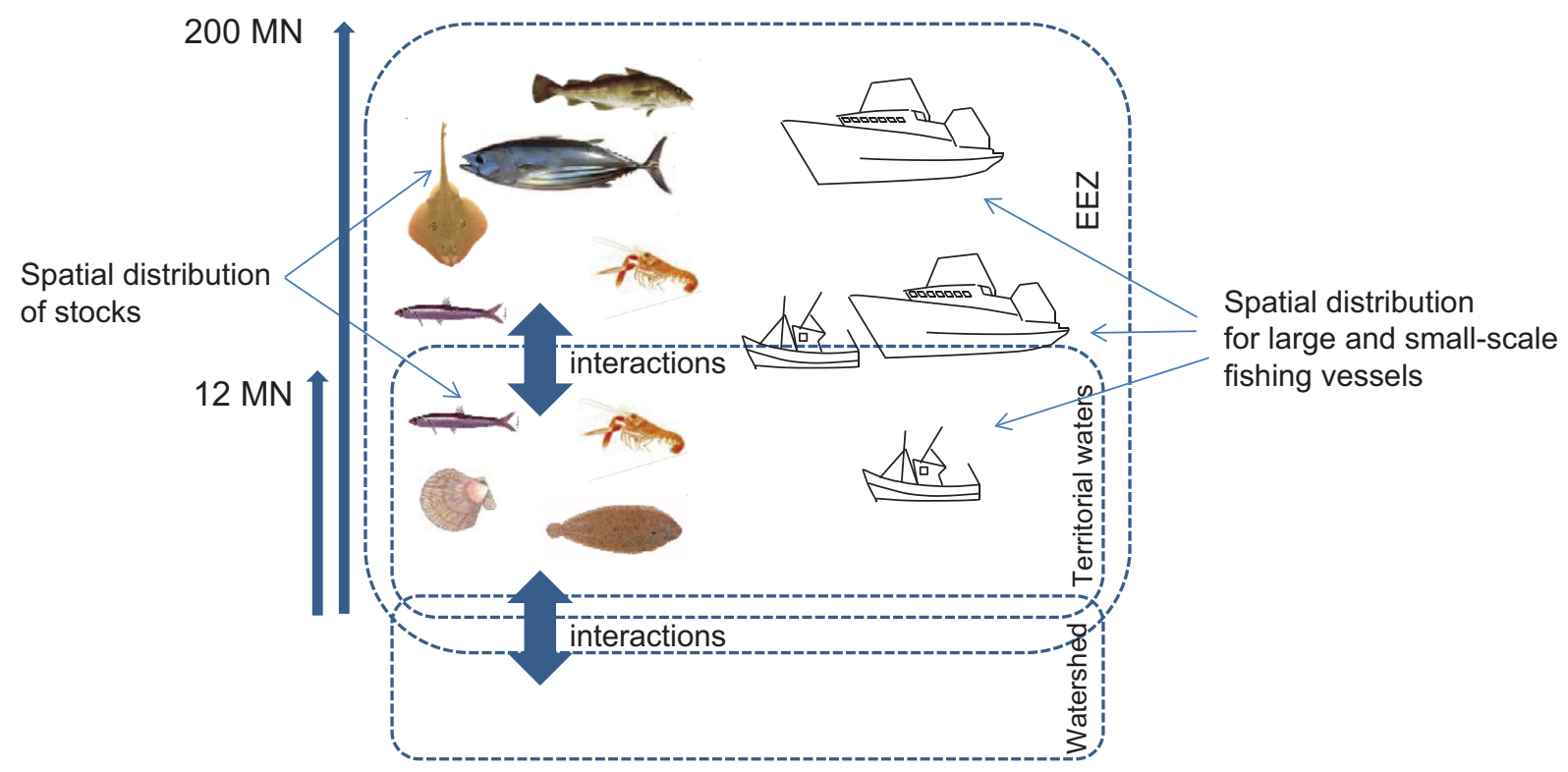

Fig. 2. Socio-system in fisheries.

species are understood in a broader sense as key resources or key ecosystem components (Fletcher et al., 2010).

\subsubsection{Key species and essential fish habitat}

The diversity of marine areas covered during the life cycle of a given species, from eggs to adults, needs to be taken into account for EBFM. For species where adults are sedentary or even attached and larval dispersion is limited, the whole life cycle takes place within a relatively restricted area. Examples are sea urchins and scallops. In contrast, pelagic species move between feeding and spawning areas, and in certain cases, migrate as larvae to nursery areas, hence they require a much wider area for their life cycle to unfold. Between these two extremes, fish, invertebrates and seaweed species display a diversity of ways of using marine spaces during their lifecycle. The concept of an essential fish habitat offers a definition of space from a marine ecology perspective. It is a space that hosts at least one life-cycle phase of a fisheries resource. The classification of essential fish habitat as conservation zones is a new tool for managing marine protected areas, based on identifying the key species in a coastal or ocean ecosystem (Delage and Le Pape, 2016).

\subsubsection{Spatial distribution of stocks and fleet mobility}

The phenomenon of spatial distribution of stocks and fleets in fisheries echoes the concept of key species and diversity in Levin's work on socio-systems. The multidisciplinary approach makes all the more sense when the aim of the research concerns the mobility of fishing vessels in relation to the spatial distribution of exploited stocks. Discrete choice models are often applied to the spatial analysis of fisheries (Bockstael and Opaluch, 1983; Ward and Sutinen, 1994; Sun et al., 2016). The distribution of fishing effort in space depends on codified and tacit knowledge (Polanyi, 1966). The first type of knowledge, such as expected market prices, abundance elements, technical criteria and weather forecasts, is easy to transmit. The second type relies on learning processes of each fisher and their positive or negative attitude towards risk. As a result, behaviour in terms of spatial mobility is variable, depending on more or less codifiable criteria. Some studies have grouped vessel mobility strategies into leaders, who are tempted to exploit new fishing areas or try out new alternative fishing techniques, and followers, who follow the leaders to break with routines (Allen and Mcglade, 1986).

Figure 2 describes a simple model of the socio-system in fisheries. Spatial delimitation is based on the 12 nautical miles (watershed and coastal zone) and 200 nautical miles limits (EEZ). From a legal point of view, this separation of marine areas is not relevant insofar as no space escapes the exclusive competence of the European Union. Quota measures apply equally to both areas.

Experience from the case studies examined here revealed that the definition of spatial scale should be based on three main criteria: stock distribution, fishing strategies, and management measures. For the Parc Naturel Marin d'Iroise, the spatial dynamics of fishermen occur within a marine protected area (Boncoeur et al., 2002; Boncoeur, 2005). For Bay of Biscay, Vermard et al. (2008) described mobility choices made by fleets following the closure of the anchovy fishery. The two case studies cover all spatial occupation strategies, both in terms of species and fleets.

\section{Case studies}

The first case study, the Parc Naturel Marin d'Iroise, is an example of a marine protected area characterised by a wide variety of coastal fisheries and Natura 2000 sites. The second case study, the Bay of Biscay, broadens the issue of a multidisciplinary approach to spatial scales, with small-scale and large-scale fisheries, and fleets originating from several EU member states (mainly France and Spain). 


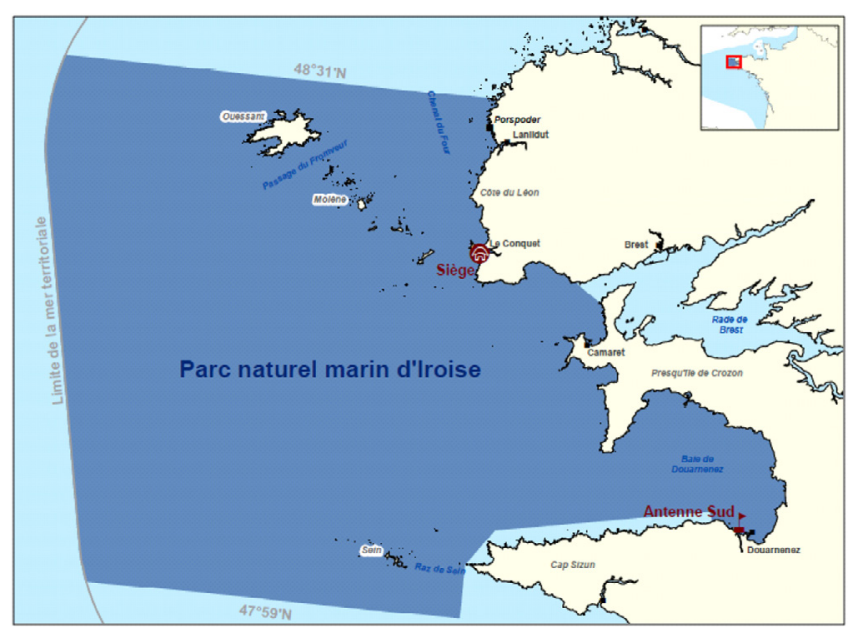

Fig. 3. Parc Naturel Marin d'Iroise.

\subsection{Parc Naturel Marin d'Iroise (PNMI): small-scale fisheries}

The aims behind the creation of a marine natural park combine knowledge about the environment, natural heritage protection, and the sustainable development of maritime activities. According to French law, a marine natural park is one of many types of marine protected areas, such as Natura 2000 sites, fishery conservation zones, nature reserves and other types of areas for protecting the marine environment. However, marine parks are not tools for managing fisheries.

The PNMI was created in 2007 and covers the maritime area of up to 12 nautical miles from the coast (Fig. 3). It was the first trial in France to manage a range of activities that put anthropogenic pressure on marine ecosystems (Boncoeur, 2005). A survey of fishing vessels revealed three categories: vessels declaring their catch in the PNMI as a main or secondary fishing source, vessels fishing adjacent to the PNMI and declaring their activity outside the limits of the park, and vessels from nearby territories (or maritime districts) and not declaring their catch in the PNMI or adjacent areas (Daurès et al., 2011). The number of investigated vessels was 642 , only 238 of which belonged to the first category (spatially located in the PNMI). From an economic perspective, the 15 species landed demonstrate the richness and diversity of the park (Leonardi et al., 2010). Some of these species are managed under European TACs, such as anglerfish, pollack and sole. Combing spatial data on fleet activity and target species provides insights into the economic dependence on the PNMI. When dependency on a species caught within the boundaries of the PNMI exceeds 50\%, the vessel is considered as specialised and vulnerable to the biological health of the proportion of the stock found within the PNMI. For three species high economic dependence was found: seabass, anglerfish - also called monkfish - , and scallops.

The lack of monitoring of fishing activities in the PNMI prevented us from drawing conclusions on any direct positive effect on the economic performance of vessels fishing in the park. Geo-referenced data partly compensates for this lack for vessels $\geq 12 \mathrm{~m}$ as they are obliged to transmit their positions as part of the vessel monitoring system (VMS). However, vessels

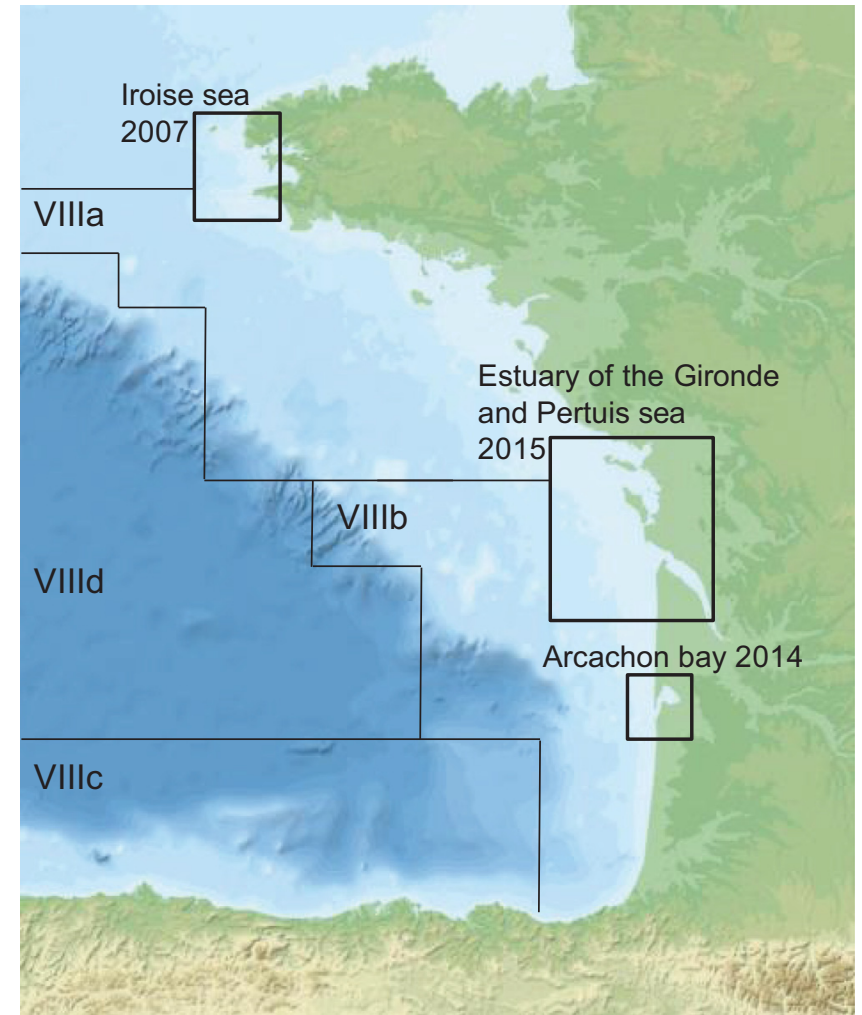

Fig. 4. The Bay of Biscay.

smaller than $12 \mathrm{~m}$ make up most of the fleets which are active in the park. The collection of spatialised production data by regular surveys has proven vital for the operational implementation of ecosystem-based fishery management (DucharmeBarth et al., 2018).

\subsection{Bay of Biscay: small-scale and large-scale fisheries}

The Bay of Biscay is an example of a spatial scale on which fishers from different EU member states operate - mainly France and Spain (Fig. 4). The recent creation of marine nature parks in the Gironde and the Pertuis Sea (2015) as well as in Arcachon Bay (2014) brings the situation of small-scale fisheries in the Bay of Biscay closer to that of the PNMI.

The Bay of Biscay is part of the marine sub-region "Bay of Biscay and Iberian waters" as defined by the Marine Strategy Framework Directive. Situated west of the French Atlantic coast, it is characterised by a large continental shelf delineated by the shelf edge and extending out to the abyssal plain. The diversity of fish species is high due to the presence of subtropical, temperate and boreal species (Lorance et al., 2009). Several recent studies have shown that there is an increasing abundance of subtropical species and a decrease in boreal species (Poulard and Blanchard, 2005; Ommer et al., 2011). The coastal zone is also very diverse, with estuaries, rias and wetlands, with a wide variety of highly productive ecosystems. Several essential fish habitat that are important for the life cycle of fisheries resources are also present in the Bay 
of Biscay, such as a hake nursery located on the La Grande Vasière, the numerous estuary-based sole nurseries, or the seabass reproduction areas located on the continental shelf (see review in Lorance et al., 2009).

Currently twenty species within the Bay of Biscay area are subject to a TAC (total allowable catch) limit. The scientific monitoring of stocks uses the functional biological unit to define the spatial distribution area. This unit traces a boundary between stocks of the same species by assuming that rates of exchange are negligible. However, managers use another spatial criterion: a management unit based on the historical rights of each EU member state. Consequently, in spatial terms, the scientific criterion (functional biological units, i.e., stocks) and the criterion of European managers do not necessarily correspond. This is a crucial point highlighted by biologists (information shared by the AFH - Association Française Halieutique, 2017), who call for a discussion on the possible forms of dialogue that can be established between all stakeholders concerned by the common resource pool. This is precisely the role of integrated marine policy, whose aim is to undertake marine spatial planning (European Parliament and Council, 2014) by taking into account interactions between activities in zones that often overlap (Gilliland and Laffoley, 2008).

To obtain maximum sustainable yield (MSY) for a fishery, the management unit criterion must correspond to the functional biological unit, for example the distribution area of a type of stock should be related to the mobility strategies of fleets (Cope and Punt, 2009).

In the 2000s, a survey similar to the one performed in the PNMI was conducted in the Bay of Biscay (Daurès et al., 2009, 2013). One of its objectives was to identify species-vessel pairs, based on the combination of ecological units (species, group of species, or spatial units) and fleets fishing one or several target species. The number of French vessels was estimated at 2000 during 2000-2006. The landing data contained more than 200 commercial species but only 20 species contributed $80 \%$ of production in tonnage. Two types of fisheries were defined using technical vessel characteristics (length and engine power) and spatial extent: small-scale fisheries (fishing mostly within $12 \mathrm{~nm}$ zone) and large scalefisheries (beyond $12 \mathrm{~nm}$ on the continental shelf). From a fisheries perspective, production means revealed a high level of concentration. Indeed, ten of the thirty identified fleets brought in $70 \%$ of landed production (in tonnage and value).

\section{Comparing the different ways of implementing ecosystem-based management in the two case studies: strengths and weaknesses}

The exemption mechanism provided by the EU for member states concerning coastal zones has focused scientific research on essential fish habitats within the 12-nautical-mile limit (Delage and Le Pape, 2016; Regimbart et al., 2017). An assessment of the institutional system established for the PNMI has fuelled discussion on the evolution of coastal space usage. It is obvious that the zones in need of protection, defined on the basis of essential fish habitat, do not solely concern the fisheries located within the coastal zone. Experiments conducted by scientists and professionals in the Bay of Biscay provide other key points for the discussion of institutional frameworks. Consultative bodies have eased communication between scientists and managers, either in a legal context for the PNMI since its creation in 2007, or more irregularly for the Bay of Biscay.

\subsection{Are marine protected areas a coherent spatial management unit for ecosystem-based fisheries management?}

The institutional framework for managing fisheries and ecosystems within the PNMI falls under the exclusive jurisdiction of the EU, but also benefits from an exemption from the principle of equal access (Art.5/1380) and a delegation of powers (Art.20/1380). Decision-making is handed over to the regional prefect as the government representative, along with the regional fishing committee. The co-decision-makers have to ask the marine park's management board for its assent when management measures are likely "to substantially modify the marine environment" (Art. L334-5 of the French Environmental Code). This specific system is constructive and creates opportunities for operationally implementing ecosystem-based fishery management. In using dialogue as a governance tool, all actors who use a defined space are likely to become active participants.

The park's management board either issues recommendation notices or gives its approval on subjects relating to professional fishing, recreational activities, water quality and access to the marine area. Decisions concerning professional fishing are taken by regional committee representatives and the regional prefect. As a result, professional fishers hold positions both in the consultation and the decision-making processes. This dual representation can lead to a conflict of interest. It can create tensions between actors in the professional fishing sphere, whose representational weight and influence in the running of the park varies.

Over the 2007-2014 period 80 recommendation notices were issued, essentially for the organisation of sea-based events. Fourteen approvals were granted, three of which concerned professional fishing and authorised an increase in the number of beach foraging licenses, while restricting the number of seine licenses to 20. An analysis of the meeting minutes shows little disagreement on requests concerning activities within the park. The most sensitive subjects are not related to the impact of fishing activities, but rather to the effects of agricultural activities on the marine environment and the occupation of space. Consequently, the question of clearing green algae from beaches - following algal blooms caused by high levels of agricultural fertilisers in coastal waters - has often been a subject of management board discussions. The issue at the heart of discussions and leading to subsequent recommendation notices concerned the impact of algae removal activities on fish nurseries, some of which produce high-value commercial species (sole, turbot, brill, etc.).

For each decision, the park's management board represents a crucial forum for ideas and actions. The results can be seen in the following examples: implementation of a restricted spiny lobster zone; spatial planning applied to farming beds of large 
seaweeds; and restriction of the fishing season for abalone on island sites.

Fishers are increasingly aware of the fact that they work in a shared space and are no longer the only economic stakeholders in the Iroise Sea. It is important to note how original and innovative this management system is, implemented within a defined space and with its continuously evolving cutting-edge management tools that combine conservation and sustainability. It is also important to recognise the effort by stakeholders (professional fishers, recreational users and scientists) to improve partnerships. These efforts are a response to the dialogue practices instigated by the park's management bodies, which fishing professionals have especially had to come to grips with.

The creation of the PNMI has encouraged dialogue through several scientific programs where fishers were accompanied on their vessels - on a voluntary basis - to evaluate the impacts of fishing gear on ecosystems (Anonymous, 2016). This has enabled new scientific data to be collected in response to the frequent tensions between different metiers in the area, mainly conflicts between small-scale coastal fishing and seine fishing (Duhamel et al., 2011). It has also enabled the impact of depredation on mammal populations to be characterised (Lefeuvre et al., 2015). Such initiatives developed in tandem with an integrated management policy strengthen dialogue as they provide a flexible framework. Although they are imperfect and there is much room for improvement, they undoubtedly open up a path for going above and beyond the highly conflictual framework for creating the marine park, towards a participative management mode, moving out of the realms of wishful thinking (Hily and Chlous-Ducharme, 2002; Van Tilbeurgh, 2006).

However, reducing the impact of fishing activities on the ecosystem in a spatial context that is coherent from the point of view of species and fleet mobility encounters many obstacles. This is where progress can be made by considering a multidisciplinary approach. The fully operational nature of ecosystem-based management applied across the PNMI as a whole largely depends on the answers provided to the following questions: Which essential fish habitat should be protected as priority? What interaction should there be with the mobility strategies of fleets? How should the local institutional system develop to reconcile spatial approaches based on both ecological indicators and economic performance indicators of fleets?

\subsection{What spatial management units are required to reconcile ecological and socio-economic objectives in the Bay of Biscay?}

The question of whether the spatial management unit is appropriate for EBFM in the Bay of Biscay has been at the heart of many a debates at national and European levels over the last decade (Bastardie et al., 2017; Boncoeur, 2005).

In the context of the Grenelle de la mer (French Ministry of Ecology, Ministère de l'écologie, 2009), fishery-based management experiments were set up. For the Bay of Biscay, the Concertation Grande Vasière project (Association du Grand Littoral Atlantique (AGLIA), 2014) brought together commercial fishing representatives, scientists and NGOs. The project dealt with the question how to manage the Norway lobster fishery on the Grande Vasière, a sandy-silty area covering part of the Bay of Biscay. The stakeholders worked on establishing a platform for dialogue, with the aim of defining a management plan for the fishery. However, the fishery-based approach put forward to reconcile the different dimensions was opposed by a fleet-based approach (economic unit) which was favoured by the professional representatives, and notably discussed within the framework of the European GEPETO project (GEstion de PEsquerias y Transnational Objectives). The project, led by the Comité Consultatif Régional Sud (Southern regional advisory committee) from 2012 to 2014 and involving administrations, professional representatives, scientists and NGOs, explored the question of which spatial management unit was most appropriate, based on different case studies, including the Bay of Biscay. The fleetbased approach was deemed more operational by the fishers and their professional representatives.

On a European level, the management of the Bay of Biscay has historically been based on a mono-specific stock-by-stock approach, using TACs as a management tool. However, TACs calculated using historical rights attributed to each member state are rarely compatible with biological units, i.e., the characterisation of a stock in its area of distribution. In the context of CFP reform and the implementation of multispecies management plans, these questions of spatial scale are now at the heart of discussions. Originally defined according to large maritime regions, multi-species management plans were intended to enable the reconciliation of fishing opportunities at spatial scales that were coherent, especially from the point of view of co-occurrence of species, to avoid by-catch and discards. At some point, the Bay of Biscay was identified in discussions as a spatial unit for defining a management plan to be applied to that same scale. Finally, it became part of preparatory work for a broader area consisting of the Bay of Biscay and Iberian waters. The management plans put forward and modelled on the Baltic plan (European Parliament and Council, 2016) were based on lists of stocks included in the management plan, and for which stock-based MSY intervals were defined with the aim of replacing the single point MSY values.

Reconciling fishing opportunities on finer spatial scales, taking into account technical interactions and species-related abundances in different ecosystems, is not actually considered in management plans, which only propose a general framework. However, it should be possible to establish regional spatial scales that take into account specificities (discard plans, marine protected areas, local institutional systems, etc.) within the management plan.

The regionalisation process of fisheries finally raises the question of existing institutions, their management competences and their appropriateness for the spatial management scale(s) to be considered. In the Bay of Biscay, the TACs and quotas are defined at a European level, divided between member states and then, in France, managed by Producer Organisations (PO) which are located along the coast. Management responsibility for French quota involves three main players: The Department for Marine Fisheries and Aquaculture is responsible for allocating and controlling national quotas on behalf of the Ministry of Agriculture and Fisheries. Producer Organisations (POs) are authorized by the 
Central State (Ministry of Agriculture and Fisheries) to manage sub-quotas. Twenty French POs were recognised by the EU in 2010 (14 located on the Atlantic coast). Vessel owners form the third player in this structure, as members or non-members of one of the POs (Le Floc'h et al., 2015). The POs pool together the rights of their members and redistribute them according to the specific rules of each PO. The POs spread along the Atlantic coast provide a certain amount of territorial coherence and generally group members together by geographic location. This said, the movement of vessels between POs and the tendency of POs to merge - more noticeably so over the last few years - has tended to cancel out their role of maintaining territorial balances. It is therefore essential to explore the question of which existing or future regional institutions are required to implement a "regionalised" ecosystem-based management of fisheries.

\section{Final remarks}

The creation and management policy of marine parks modelled on the PNMI has constantly encouraged stakeholders to work together. Other obstacles need to be overcome to completely ensure that fragile environments in coastal areas are properly protected (Chlous-Ducharme, 2004). Data on fleet mobility behaviour from spatialised observations should be used to help bring the two concepts of spatial dimensions together: biological units characterised by the distribution of harvested stocks, and management units based on historical rights.

The challenge for European countries is to move towards an operational EBFM. In this case, the boundaries of common resource pools as well as institutional embedding are two main properties in the definition of a socio-ecological system taking into account all pressures (all activities in the same area), not only from fisheries. It remains to integrate other properties (reduction of economic divergence, minimal recognition of fishing rights, common mechanisms of conflict resolution) to achieve full EBM under the scheme of the CFP, integrated in the MSFD. The key of the success, moving from SSFM to EBFM or EBM, is placed in the hands of stakeholders (fishing industry, NGOs, consumers, local managers and scientists). Stakeholder involvement has been identified as one of the four main priorities to close conceptual and empirical approaches of EBFM/EBM (Long et al., 2017). The PNMI case study offers an interesting experience but remains strongly constrained with an institutional framework not fully decentralized as long as local fisheries management in still under the authority of fishermen and the State, represented by the regional prefect.

The institutional arrangement appropriate for EBFM/EBM should be a decentralized governance where fishermen have to prove not "to harm key components of the ecosystem" (Pikitch et al., 2004). In the literature devoted to institutions in fisheries, three decentralized models have been described (Sen and Nielsen, 1996). The first one is co-management by partnership where the Government and users are decision-making partners. The second option is co-management by delegation. Users are decision-makers, but endorsed by the Government. The third possibility, the more ambitious one, is industry self-management with reversal of the burden of proof. Stakeholders, not only fishermen, are decision-makers, informing the Government. The most appropriate institutional arrangement will depend on the characteristics of the case study, boundaries and spatial scale, local institutions and the diversity of stakeholders, key species and fleet mobility. It will in any case raise and challenge the question of multidisciplinarity in theory and practice.

Acknowledgements. The research has received funding from Labex MER (Institut Universitaire Européen de la mer). The article also benefited from comments of two anonymous referees and a detailed proofreading from the Co-editor in Chief.

\section{References}

Acheson JM. 1975. The lobster fiefs: economic and ecological effects of territoriality on the Maine lobster industry. Human Ecol 3: 183-207.

Alban F, Le Floc'h P, Boncoeur J. 2004. The impact of economic and regulatory factors on the relative profitability of fishing boats: a case study of the seaweed harvesting fleet of Northwest Brittany (France), Aquat Living Res 17: 185-193.

Allen PM, Mcglade J. 1986. Dynamics of discovery and exploitation: the case of the Scotian shelf groundfish fisheries. Can J Fish Aquat Sci 43: 1187-1200.

Anonyme Bilan des embarquements à bord des navires de pêche professionnelle volontaires dans le Parc naturel marin d'Iroise, Comité Départemental des pêches du Finistère, PNMI, Ifremer, 2016, p. 16.

Arthur WB. Increasing returns and path dependence in the economy, University of Michigan Press, Ann Arbor, 1994

Arthur WB. 1989. Competing technologies, increasing returns, and lock-in by historical events. Econ J 99: 116-131.

Association du Grand Littoral Atlantique (AGLIA), 2014. Concertation pour une pêche durable sur la Grande Vasière - une expérimentation d'UEGC, http://www.aglia.fr/images/Projet/arti cle/13/pdf/78-rapport_final_cgv_internetsmall-part1.pdf

Association Française Halieutique (AFH), 2017. Fixation des quotas de pêche 2017: pour de trop nombreux stocks, les ministres ne pourront pas suivre l'avis scientifique, communication, https:// www.association-francaise-halieutique.fr

Bastardie F, Angelini S, Bolognini L, et al. 2017. Spatial planning for fisheries in the Northern Adriatic: working toward viable and sustainable fishing. Ecosphere 8: e01696.

Berkes F. 2006. From community-based resource management to complex systems: the scale issue and marine commons. Ecol Soc 11: 45 .

Berkes F, Folke C. (Eds.), Linking Social and Ecological Systems. Management Practices and Social Mechanisms for Building Resilience, Cambridge University Press, Cambridge, 1998

Berkes F, Feeny D, McCay B, Acheson J. 1989. The benefits of the commons. Nature 340: 91-93.

Biedron IS, Knuth BA. 2016. Toward shared understandings of ecosystem-based fisheries management among fishery management councils and stakeholders in the US Mid-Atlantic and New England regions. Mar Policy 70: 40-48.

Bockstael NE, Opaluch JJ. 1983. Discrete modelling of supply response under uncertainty: the case of the fishery. J Environ Econ Manag 10: 125-137.

Boncoeur J. Un modèle de gestion halieutique spatialisée, in Boncoeur J. (coord.), Activités halieutiques et activités récréatives dans le cadre d'un espace à protéger: le cas du Parc National de la 
Mer d'iroise, Les publications Amure, série rapport n R-05 2005, 2005 pp. 249-275

Boncoeur J, Alban F, Guyader O, Thébaud O. 2002. Fish, fishers, seals and tourists: economic consequences of creating a marine reserve in a multi-species, multi-activity context. Nat Res Modeling 15: 387-411.

Bousquet F, Botta A, Alinovi L., Barreteau O, Bossio D, Brown K, Caron P, Cury P, Errico M, DeClerck F, Dessard H, Kautsky EE, Fabricius C, Folke C, Fortmann L, Hubert B, Magda D, Mathevet R, Norgaard RB, Quinlan A, Staver C. 2016. Resilience and development: mobilizing for transformation. Ecol Soc 21: 40.

Charles AT. 1992. Fishery conflicts - a unified framework, Mar Policy 16: 379-393.

Chlous-Ducharme F. 2004. L'archipel de Molène et « l'autre bord », Ethnologie française 1: 113-122.

Churchill R, Owen D. The EC Common Fisheries Policy, Oxford EC Law Library, 2010

Cope JM, Punt AE. 2009. Drawing the lines: resolving fishery management units with simple fisheries data. Can J Fish Aquat Sci 66: 1256-1273.

Cormier R, Kelble CR, Anderson MR, Allen JI, Grehan A, Gregersen O. 2017. Moving from ecosystem-based policy objectives to operational implementation of ecosystem-based management measures, ICES Mar Sci 74: 406-413.

Coulthard S. 2012. Can we be both resilient and well, and what choices do people have? Incorporating agency into the resilience debate from a fisheries perspective. Ecol Soc 17: 4.

Daurès F, Alban F, Frangoudes K, Le Grand C. Situation économique de la flotte de pêche professionnelle du Parc Naturel Marin de l'Iroise (PNMI), série Rapports R-24-2012, 2011, p 75

Daurès F, Rohet M-J, Van Iseghem S, Trenkel VM. 2009. Fishing fleet typology, economic dependence, and species landing profiles of the French fleets in the Bay of Biscay, 2000-2006. Aquat Living Res 22: 535-547.

Daurès F, Trenkel VM, Guyader O. 2013. Modelling the fishing costs of French commercial vessels in the Bay of Biscay. Fish Res 146: 74-85.

Delage N, Le Pape O. Inventaire des zones fonctionnelles pour les ressources halieutiques dans les eaux sous souveraineté française - Première partie: définitions, critères d'importance et méthode pour déterminer des zones d'importance à protéger en priorité, Les publications du Pôle halieutique Agrocampus Ouest, Rennes, 44, 2016, p 36

Ducharme-Barth ND, Shertzer KW, Ahrens RNM. 2018. Indices of abundance in the Gulf of Mexico reef fish complex: a comparative approach using spatial data from vessel monitoring systems. Fish Res 198: 1-13.

Duhamel E, Laspougeas C, Fry A. Rapport final du programme d'embarquements à bord des bolincheurs travaillant dans le Parc naturel marin d'Iroise, Ifremer, Plouzané, 2011 p 41

Durrenberger EP, Palsson G. 1987. Ownership at sea: fishing territories and access to sea resources. Am Ethnol 14: 508-522.

Eliasen SQ, Hegland TJ, Raakjaer J. 2015. Decentralising: the implementation of regionalisation and co-management under the post-2013 common fisheries policy. Mar Policy 62: 224-232.

European Parliament and Council. Regulation (EU) no. 1380/2013 of the European Parliament and of the Council of 11 December 2013 on the Common Fisheries Policy, amending Council Regulations (EC) no. 1594/2003 and (EC) no. 1224/2009 and repealing Council Regulations (EC) no. 2371/2002 and (EC) no. 639/2004 and Council Decision 2004/585/EC, 2013

European Parliament and Council. Directive 2014/89/EU of the European Parliament and of the Council of 23 July 2014 establishing a framework for maritime spatial planning, Official Journal of the European Union, 2014

European Parliament and Council.Regulation (EU) 2016/1139 of the European Parliament and of the Council of 6 Jult 2016 establishing a multiannual plan for the stocks of cod, herring and sprat in the Baltic Sea and the fisheries exploiting those stocks, amending Council Regulation (EC) no. 2187/2005 and repealing Council Regulation (EC) no. 1098/2007, 2016

Fletcher WJ, Shaw J., Metcalf SJ, Gaugham DJ. 2010. An ecosystem based fisheries management framework: the efficient, regionallevel planning tool for management agencies. Mar Policy 34: 1226-1238.

Gilliland PM, Laffoley D. 2008. Key elements and steps in the process of developing ecosystem-based marine spatial planning. Mar Policy 32: 787-796.

Grafton Q. 2005. Social capital and fisheries governance. Ocean Coast Manag 48: 753-766.

Guyader O, Berthou P, Koutsikopoulos C et al. 2013. Small scale fisheries in Europe: a comparative analysis based on a selection of case studies. Fish Resh 140: 1-13.

Gutierrez NL, Hilborn R, Defeo O. 2011. Leadership, social capital and incentives promote successful fisheries. Nature 470: 386-389.

Hily C, Chlous-Ducharme F. Le parc national marin de la mer d'Iroise, un exemple inédit de conservation et de gestion durable de l'espace maritime, in: Dauvin J-C. (coord.), Gestion intégrée des zones côtières: outils et perspectives pour la préservation du patrimoine naturel, Patrimoines naturels, 57, 2002, pp. 258-265.

Holling CS. 2001. Understanding the complexity of economic, ecological, and social systems. Ecosystems 4: 390-405.

ICES. Bay of Biscay and Iberian Waters Ecosystem overview in ICES advice 2016, Book 7, 2016, p 15.

Jentoft S. 1989. Fisheries co-management: delegating government responsibility to fishermen's organizations. Mar Policy 13: 137154.

Lefeuvre C, Laspougeas C, Mariat-Roy E, Geistdoerfer A, Hassani S, Jung J-C, Méheust E. Interactions pêche mammifères marins INPECMAM Iroise, rapport final, octobre 2014, $2015 \mathrm{http}: / /$ www.parc-marin-iroise.fr/Peche-Economie/Peche-durable/ Peche-et-mammiferes-marins/Interactions-entre-peche-et-mammi feres-marins

Le Floc'h P, Murillas A, Aranda M, Daurès F, Fitzpatrick M, Guyader O, Hatcher A, Macher C, Marchal P. 2015. The regional management of fisheries in European Western Waters. Mar Policy 51: 375-384.

Le Floc'h P, Wilson JR. 2017. Les pêches maritimes françaises 1983-2013, Presses universitaires de Rennes, Rennes, 213p

Leonardi S, Begot E, Le Grand C, Pitel-Roudaut M, Laurans M, Daurès F, Berthou $\mathrm{P}$, Alban F, Frangoudes K, Leblond E, Demanèche S. Etude sur l'état des lieux de la pêche professionnelle dans le Parc Naturel Marin d'Iroise, Plouzané, 2010, $119 \mathrm{p}$

Leslie HM, McLeod KL. 2007. Confronting the challenges of implementing marine ecosystem-based management. Front Ecol Environ 5: 540-548.

Levin SA. 1998. Ecosystems and the biosphere as complex adaptative systems. Ecosystems 1: 431-436.

Levin SA, Barett S, Anuyar S et al. 1998. Resilience in natural and socioeconomic systems. Environ Dev Econ 3: 221-262.

Levin SA. 2000. Multiple scales and the maintenance of biodiversity. Ecosystems 3: 498-506.

Link JS, Browman HI. 2014. Integrating what? Levels of marine ecosystem-based assessment and management. ICES J Mar Sci 71: 1170-1173. 
Long RD, Charles A, Stephenson RL. 2017. Key principles of ecosystem-based management: the fishermen's perspective. Fish Fish 18: 244-253.

Lorance P, Bertrand JA, Brind'Amour A, Rochet M-J, Trenkel VM. 2009. Assessment of impacts from human activities on ecosystem components in the Bay of Biscaye in the early 1990s. Aquat Living Res 22: 409-431.

Mariat-Roy E. 2014. When fishing means resilience. The evolution of small boat fishing practices in Iceland since 1990 and the new development of long-line fishing. Polar Records 50: 421-429.

Mazé C, Dahou T, Ragueneau O, Danto A, Mariat-Roy E, Raimonet M, Wiesbein O. 2017. Knowledge and power in integrated coastal management. For a political anthropology of the sea combined with the sciences of the marine environment. Géoscience 349: 359-368. https://doi.org/10.1016/J.CRTE2017.09.008

Ministère de l'écologie, 2009. Le livre Bleu des engagements du Grenelle de la Mer, 10 et 15 juillet 2009, 71p, http://www.ladocumentation francaise.fr/rapports-publics/094000356/index.shtml

Nelson R, Winter SG. An evolutionary theory of economic change, Cambridge, Belknap Press, Harvard University Press, 1982

North D. 1991. Institutions. J Econ Perspect 5: 97-112.

North DC. Institutions, institutional change and economic performance, Cambridge University Press, Cambridge, 1990

Ommer RE, Perry I, Cochrane K, Cury P. World fisheries: a socialecological analysis. Fish Aquat Res Series, West, Wiley, Sussex, 2011

Ostrom E. Governing the commons: the evolution of institutions for collective action, Cambridge University Press, Cambridge, UK, 1990

Ostrom E. Polycentric systems as one for solving collective-action

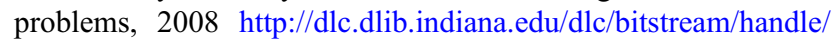
10535/4417/W08-6_Ostrom_DLC.pdf

Ostrom E. 2010. Beyond markets and states: polycentric governance of complex economic systems. Am Econ Rev 100: 1-33.

Palmer C, Sinclair P. When the Fish are Gone: Ecological Disaster and Fishers in Northwest Newfoundland, Fernwood Publishing, Halifax, 1997

Parsons SL. La gestion des pêches maritimes au Canada, Ottawa, Conseil National de Recherches, 1995

Pascoe S, Coglan L, Mardle S. 2001. Physical versus harvest-based measures of capacity: the case of the United Kingdom vessel capacity unit system. ICES J Mar Sci 58: 1243-1252.

Pierson P. 2000. Increasing returns, path dependence and the study of politics. Am Politi Sci Rev 94: 251-267.

Pikitch EK, Santora C, Babcock EA. et al. 2004. Ecosystem-based fishery management, Science, 305: 346-347.
Platteau, J-P. 2004. Monitoring elite capture in community-driven development, Dev Chang 35: 223-246.

Polanyi M. The Tacit Dimension, Doubleday, Garden City, NY, 1966

Poulard J-C, Blanchard F. 2005. The impact of climate change on the fish community structure of the eastern continental shelf of the Bay of Biscay. ICES J Mar Sci 62: 1436-1443.

Regimbart A, Guitton J, Le Pape O. Inventaire des zones fonctionnelles pour les ressources halieutiques dns les eaux sous souveraineté française - Deuxième partie: Inventaire des zones fonctionnelles halieutiques, Agrocampus Ouest no. 46, Rennes, 2017 , p. 171

Sanchirico JN, Smith MD, Lipton DW. 2008. An empirical approach to ecosystem-based fishery management. Ecol Econ 63: 586596.

Schrank WE. 2005. The Newfoundland fishery: ten years after the moratorium. Mar Policy 29: 407-420.

Sen S, Nielsen JR. 1996. Fisheries co-management: a comparative analysis. Mar Policy 20: 405-418.

Smith ADM, Fulton EJ, Hobday AJ, Smith DC, Shoulder P. 2007. Scientific tools to support the practical implementation of ecosystem-based fisheries management. ICES J Mar Sci 64: 633-639.

Sun J, Hinton MG, Webster DG. 2016. Modeling the spatial dynamics of international tunafleets. PLoS ONE 11(8): 0159626.

Trawick PB. 2001. Successfully governing the commons: principles of social organization in an Andean irrigation system. Human Ecol 29: $1-25$.

Van Hoof L. 2015. Fisheries management, the ecosystem approach, regionalization and the elephants in the room. Mar Policy 60: 2026.

Van Tilbeurgh V. Quand la gestion intégrée redessine les contours d'une aire protégée : le cas du parc marin en mer d'Iroise, Vertigo, 7, 2006, 3

Vermard Y, Marchal P, Mahévas S, Thébaud O, 2008. A dynamic model of the Bay of Biscay pelagic fleet simulating fishing trip choice: the response to the closure of the European anchovy (Engraulis encrasicolus) fishery in 2005. Can J Fish Aquat Sci 65: 2444-2453.

Villasante S, Macho G, Antelo M, Rodriguez-Gonzalez D, Kaiser MJ. 2013. Resilience and challenges of marine social-ecological systems under complex and interconnected drivers. Ambio 42: 905-909.

Walker B, Holling CS, Carpenter SR, Kinzig A. 2004. Resilience, adaptability and transformability in social-ecological systems. Ecol Soc 9: 5.

Ward JM, Sutinen JG. 1994. Vessel entry-exit behavior in the Gulf of Mexico shrimp fishery. Am J Agricl Econ 76: 916-923.

Cite this article as: Le Floc'h P, Bertignac M, Curtil O, Macher C, Mariat-Roy E, Paulet Y-M. 2018. A multidisciplinary approach to the spatial dimension in ecosystem-based fisheries management. Aquat. Living Resour. 31: 23 